\title{
Preservation of Some Physico-Chemical Properties of Soymilk-Based Juice with Aframomum Danielli Spice Powder
}

\author{
A.O Dauda*, G.O. Adegoke \\ Department of Food Technology, University of Ibadan, Ibadan, Oyo State, Nigeria, West Africa \\ *Corresponding author: adegboladauda@yahoo.com
}

Received May 30, 2014; Revised July 22, 2014; Accepted August 04, 2014

\begin{abstract}
The effect of Aframomum danielli powder on the shelf life of physico-chemical properties of soy-milk based juice was studied. In this paper, attempt was made to investigate the preservative effect of the powder of Aframomum danielli, a local spice, on the physico-chemical properties of blends of soymilk and juices from fruits and vegetable by prolonging its shelf life. This was done by adding $0.5-3.0$ grams of the spice powder to every $200 \mathrm{ml}$ of the blend, while the control samples had no spice. The juice quality was analyzed for sensory attributes and physico-chemical parameters over six month's period of storage at interval of four weeks. Sensory evaluation of the juices was judged for colour, flavour, taste and general acceptability, on a nine-point hedonic scale, varying from "dislike extremely" (score 1) to "like extremely" (score 9), according to the method of [39]. Ten (10) untrained panel members carried out the sensory evaluation. Infrared spectrophotometer was used to identify functional groups in the powder of the spice, Aframomum danielli, responsible for the stability of the juice. Differences were observed in the colour and aroma of treated samples in comparison with the control, though the samples were generally accepted. The percentage losses recorded for the total soluble solids, ascorbic acids and total sugars of treated samples were far lesser than those of control over the same condition and period of storage. Some of the active components of the spice identified are 4-amino-acetophenone, N,N-dimethyl-2-chloroacetoacetamide, 3-beta-acetoxy-5-etienic acid, 6,10-dimethylundeca-5,9,-diene2-one, Phenyl-3-buten and 4-Phenyl butanone. The samples treated with the Aframomum danielli powder were better preserved than the untreated ones (control).
\end{abstract}

Keywords: Aframomum danielli powder, soymilk, juice, shelf life, active components, preservative

Cite This Article: A.O Dauda, and G.O. Adegoke, "Preservation of Some Physico-Chemical Properties of Soymilk-Based Juice with Aframomum Danielli Spice Powder." American Journal of Food Science and Technology, vol. 2, no. 4 (2014): 116-121. doi: 10.12691/ajfst-2-4-2.

\section{Introduction}

Fruits and vegetables are among the most important foods of mankind as they are not only nutritive but are also indispensable for the maintenance of health. Fresh fruits and vegetables are an essential component of a healthy diet, able to decrease the risk of cardiovascular diseases and cancer [3]. Apart from their nutritional and sensory properties, fruits and vegetables are currently recognized as active and protective agents [31].

In the last years, their consumption has continued to grow rapidly, which was linked to the increased public awareness of their health benefits, even if it remains below the recommended daily intake in many countries, due to barriers such as complacency and lack of willpower to change the diet [35]. However, this new trend has also hiked the chances of outbreaks of food poisoning and food infection related to consumption of fresh fruits and uncooked salad [6]. Fruits and vegetables have been cultivated since ancient times [28]. Fruits are not only consumed fresh but also used to produce jam, jelly, stewed fruit, marmalade, syrup and several types of soft drinks. Citrus fruits have been reported to be rich in antioxidants compounds, particularly ascorbic acid and phenols $[13,19,36]$. Ascorbic acid is well known for its strong antioxidant activity [15], while phenolic compounds have been widely investigated and characterized for their anticancer properties [18,20,24].

Today's society is characterized by an increasing health consciousness and growing interest in the role of food for maintaining and improving human well-being and consumer health. Many studies have been done on the physical, chemical and nutritional properties of fruits, such as sweet cherry $[28,33,34,44]$, Plum $[14,16]$, wild plum [8], Orange [40], berries [27,22]. Various methods have equally been reported to have been used for the preservation of juices and shelf life evaluation equally reported by many scientists. Hot fill and aseptic methods were reported by [11] to be efficient in maintaining physico-chemical characteristics of juice up to twelve months. Clarified cashew apple juice along with tannase treatment stored at $4^{\circ} \mathrm{C}$ was stable for two months [9]. It was also reported by [21] that cashew apple juice 
preserved with aqueous extract (hot and cold) of Aframomum danielli showed reduction in the vitamin $\mathrm{C}$ contents and sugars after two weeks. Also, [5] used a combined method of preservation i.e drying of cashew apples with osmotic dehydration and observed that osmotic pretreatment was efficient in reducing water activity but not effective in protecting the juice from oxidation.

High Pressure (HP) processing of fruit and vegetable, which is another method of preservation, offers the chance of producing food of high quality, greater safety and increased shelf-life [7]. The main requirement this new technology must meet is to ensure product microbial safety while preserving sensory and nutritional characteristics to obtain products more similar to fresh foods [41]. High pressure processing (HPP) can enable ready to drink juice processors to produce innovative products with fresh-like, natural-like attributes and natural-looking colours which are all aspects valued by consumers nowadays [12]. Increasingly, consumers not only want food products to be of high (sensory) quality but also to deliver specific benefits in terms of health, safety and environmental quality [43].

In the last two decades or thereabout, food scientists have attempted to develop new technologies that improve the quality and quantity of products, while consumers have also become more critical on the use of synthetic additives to preserve food safety or enhance characteristics such as colour and flavour [10]. The growing demand for slightly processed products with the same guarantees of quality or better than those treated by traditional methods of preservation has urged researchers to focus most of their efforts on studying new ways of extending the shelf life of fresh produce.

Soymilk, another key component of the blend, (also called soyamilk, or soybean juice and sometimes referred to as soydrink/beverage) is a beverage made from soybeans (Glycine max). It is a stable emulsion of oil, water, and protein. Soymilk is produced by soaking dry soybeans and grinding with water in a Hammer mill before cooking at boiling point for about 20 minutes. Soymilk contains similar proportion of protein as cow's milk; around $3.5 \%$ and $2 \%$ fat, $2.9 \%$ carbohydrate, and $0.5 \%$ ash. They have been blended with other food products to produce other products, most likely, with better nutritional qualities. Milk-based products all contain actual milk (and/or soymilk) or different combinations of modified proteins. Most of the popular milk-based beverages are good sources of protein, containing 10 to 40 grams per serving.

In recent times, spice antioxidants have raised considerable interest among food scientists, manufacturers, and consumers because of their natural antioxidants [26]. Consumers are increasingly aware of the risk posed by synthetic antioxidants due to their high volatility and instability at elevated temperature, hence the need to shift focus to the use of natural antioxidants [1,29,30]. Aframonium danielli, a natural antioxidant and spice has shown its potential as a preservative in some food system $[2,17]$.

The genus "Aframomum" has about 50 species spread over West and East Africa and the wetter parts of tropical Africa from Senegal and Ethiopia to Mozambique and Angola [25]. Aframomum species are well known for their fruits with aromatic seeds, of which Aframomum danielli is the most common. Aframomum danielli tree is a large robust perennial plant ( $3-4 \mathrm{~m}$ tall) found in Central and West African countries. It belongs to the family Zingiberaceae. It is known as "Oloburo" or "atare aja” in Yoruba speaking regions of Nigeria. The pods are usually brown in their dried state. The seeds are oval (about 2$3 \mathrm{~mm}$ in diameter), olive brown and shiny in appearance and are commonly used for traditional dishes, especially pepper soup. The essential oil is used in dye preparations and flavorings.

In this paper, the aim is to give an insight into the knowledge or the use of Aframomum danielli, a local spice, in ensuring the physico-chemical stability and quality of soymilk-based juice.

\section{Materials and Methods}

Aframomum danielli pods were purchased from a local market in Ibadan, Oyo State, Nigeria. The seeds were removed from the pods and cleaned of the extraneous materials. The seeds were winnowed and milled into powder using hammer mill. The powder was then sieved with a wire-mesh to obtain fine powder and stored at room temperature for use. Aframomum danielli powder (0.5g $3.0 \mathrm{~g}$ ) was added to every $200 \mathrm{ml}$ of the juice blends.

\subsection{Juice Preparation}

Fresh oranges were collected from a local farm at Ajibode village in Ibadan. Carrot and watermelon were purchased from Sabo in Ibadan, while the soybeans used for soymilk was obtained from International Institute for Tropical Agriculture (IITA) in Ibadan. These fresh, juicy, good quality fruits and vegetable were sorted for processing. The fruits and vegetable were weighed, washed thoroughly under tap water to remove foreign materials. Juices were extracted, filtered through sterilized muslin cloth with an average yield of $620 \mathrm{ml} / \mathrm{kg}$ of each fruit and vegetable used. The soybeans were cleaned properly, soaked in water at $\left(30^{\circ} \mathrm{C}\right.$ for 5 hours), grinded (with hammer mill), slurry cooked (at boiling point for 20 minutes), separation of the cooked soymilk from fibre and boiling of the resulting filtrate to obtain soymilk. The laboratory prepared soymilk, juice from the vegetable and fruits were blended in equal ratios. Every $200 \mathrm{ml}$ of the blend was treated with powder of Aframomum danielli $(0.5 g-3.0 g)$.

\subsection{Shelf Life Study}

The shelf life study of the soymilk-based juice was based on sensory and physico-chemical quality of the juice products.

\subsection{Sensory Analysis}

Sensory evaluation of the juices was carried out on the colour, flavour, taste and general acceptability using a nine-point hedonic scale, varying from "dislike extremely" (score 1) to "like extremely" (score 9) according to a method of [39]. 10 untrained panel members carried out the sensory evaluation. The juices were served in a coded and transparent white glass cups 
for proper assessment. The juices were served in triplicate and coded separately.

\section{Physico-Chemical Analyses}

pH of the juice was determined by weighing 10 grams $(\mathrm{v} / \mathrm{w})$ of the test portions into a clean Erlenmeyer. The decanted supernatant in a $250 \mathrm{ml}$ beaker was used to determine the $\mathrm{pH}$ using electrode and pentiometer standardized with buffer solutions of $\mathrm{pH} 9.18$ and 4.01 at temperature $25^{\circ} \mathrm{C}$ and expressed as $\mathrm{pH}$ units.

Total Soluble Solids (TSS) was determined using a hand digital refractometer (Atago, Tokyo model Leica 10431) according to the method of [45].

Total Titratable Acidity was determined by titrating $10 \mathrm{ml}$ of the extract (juice) with $0.1 \mathrm{~N} \mathrm{NaOH}$ after $1 \mathrm{ml}$ of the sample was diluted into $100 \mathrm{ml}$ volumetric flask, $1 \%$ phenolphthalein added and shaked properly. It was then titrated.

Vitamin C content (in $\mathrm{mg} / 100 \mathrm{ml}$ ) was determined using High Performance Liquid Chromatography (HPLC).

Total sugar from the juice was done according to the method of analysis by [45].

Statistical Analysis: Data were analysed using (ANOVA) at $\mathrm{P}=0.05$.

\section{Result and Discussion}

Sensory Analysis: There were significant differences in the colour and aroma of the samples. After the period of storage, it was noticed that the colour which was slightly cloudy (treated samples) began to depreciate. The hedonic scale rating of both the untreated (represented by CTR) and treated samples showed that they were accepted. There was no significant difference in the overall acceptability of the samples over the period of storage, though the colour experienced little change (Table 1). The changes experienced in the colour of the samples could be due to the elimination of coloured pigments (carotenoids and others) from the fresh juice. After three and half months of storage, the juice was not acceptable.

Table 1. Sensory Evaluation (mean hedonic scores) of the Treated and Untreated Samples of COWS

\begin{tabular}{ccccc}
\hline Sample & $\begin{array}{c}\text { Colour } \\
\text { /Appearance }\end{array}$ & Taste & $\begin{array}{c}\text { Aroma } \\
\text { /Flavour }\end{array}$ & $\begin{array}{c}\text { Overall } \\
\text { acceptability }\end{array}$ \\
\hline CTR & $6.73^{\mathrm{a}}$ & $6.27^{\mathrm{a}}$ & $6.07^{\mathrm{bc}}$ & $6.17^{\mathrm{a}}$ \\
A & $6.25^{\mathrm{ab}}$ & $6.33^{\mathrm{a}}$ & $5.83^{\mathrm{ab}}$ & $6.20^{\mathrm{a}}$ \\
B & $6.25^{\mathrm{ab}}$ & $6.27^{\mathrm{a}}$ & $5.57^{\mathrm{b}}$ & $6.33^{\mathrm{a}}$ \\
C & $5.72^{\mathrm{b}}$ & $6.00^{\mathrm{a}}$ & $5.37^{\mathrm{c}}$ & $6.20^{\mathrm{a}}$ \\
D & $5.03^{\mathrm{c}}$ & $5.80^{\mathrm{a}}$ & $5.37^{\mathrm{c}}$ & $6.03^{\mathrm{a}}$ \\
E & $5.13^{\mathrm{bc}}$ & $6.03^{\mathrm{a}}$ & $5.80^{\mathrm{ab}}$ & $6.03^{\mathrm{a}}$ \\
F & $5.73^{\mathrm{b}}$ & $6.17^{\mathrm{a}}$ & $6.37^{\mathrm{a}}$ & $6.20^{\mathrm{a}}$ \\
\hline
\end{tabular}

Superscripts down a column are significantly difference with $\mathrm{a}>\mathrm{b}>\mathrm{c}>\mathrm{d}$. Means for each attributes followed by the same letter are not significantly different at $5 \%$ level by Tukey.

$\mathrm{CTR}=\quad$ Control samples (untreated Samples)

A $=$ Juice blend treated with 3 grams of Aframomum danielli powder

$\mathrm{B}=$ Juice blend treated with 2.5 grams of Aframomum danielli powder
C

$\mathrm{D}$

Aframomum danielli powder

$\mathrm{E} \quad=\quad$ Juice blend treated with 1.0 grams of Aframomum danielli powder

$\mathrm{F} \quad=\quad$ Juice blend treated with 0.5 grams of Aframomum danielli powder

COWS $=\quad$ Blends of Carrot, Oranges, Watermelon and Soymilk

\section{Physico-Chemical Analyses}

The results are as shown in Table 2 to Table 6. The $\mathrm{pH}$ values of the preserved juice samples decreased from 4.97-3.88 (Table 2) over the period of storage (180 days). The decrease could be attributed to the growth of microorganism that produced lactic acid. Most bacteria will not grow at low $\mathrm{pH}$ and hence good keeping quality of the juice was maintained.

Table 2. pH of Blends of Carrot, Oranges, Watermelon and Soymilk Treatment with Aframomum danielli Powder (in grams)

\begin{tabular}{cccccccc}
\hline $\begin{array}{c}\text { Storage Time } \\
\text { (in weeks) }\end{array}$ & $\mathbf{3 g}$ & $\mathbf{2 . 5 g}$ & $\mathbf{2 . 0 g}$ & $\mathbf{1 . 5 g}$ & $\mathbf{1 . 0 g}$ & $\mathbf{0 . 5 g}$ & $\mathbf{C T R}$ \\
\hline 0 & $4.97 \mathrm{a}$ & $4.93 \mathrm{a}$ & $4.66 \mathrm{a}$ & $4.89 \mathrm{a}$ & $4.95 \mathrm{a}$ & $4.88 \mathrm{a}$ & $4.91 \mathrm{a}$ \\
4 & $4.95 \mathrm{a}$ & $4.79 \mathrm{~b}$ & $4.55 \mathrm{~b}$ & 4.83 & $4.91 \mathrm{a}$ & $4.76 \mathrm{~b}$ & $4.82 \mathrm{~b}$ \\
8 & $4.89 \mathrm{~b}$ & $4.61 \mathrm{c}$ & $4.53 \mathrm{~b}$ & $4.74 \mathrm{~b}$ & $4.77 \mathrm{~b}$ & $4.67 \mathrm{c}$ & $4.63 \mathrm{c}$ \\
12 & $4.84 \mathrm{c}$ & $4.52 \mathrm{~d}$ & $4.46 \mathrm{c}$ & $4.46 \mathrm{c}$ & $4.60 \mathrm{c}$ & $4.51 \mathrm{~d}$ & $4.52 \mathrm{~d}$ \\
16 & $4.78 \mathrm{~d}$ & $4.38 \mathrm{e}$ & $4.40 \mathrm{c}$ & $4.40 \mathrm{c}$ & $4.48 \mathrm{~d}$ & $4.37 \mathrm{e}$ & $4.44 \mathrm{e}$ \\
20 & $4.68 \mathrm{e}$ & $4.19 \mathrm{f}$ & $4.07 \mathrm{~d}$ & $4.07 \mathrm{~d}$ & $4.32 \mathrm{e}$ & $4.22 \mathrm{f}$ & $3.97 \mathrm{f}$ \\
24 & $4.61 \mathrm{f}$ & $3.93 \mathrm{~g}$ & $3.88 \mathrm{e}$ & $3.88 \mathrm{e}$ & $4.18 \mathrm{f}$ & $4.16 \mathrm{~g}$ & $3.75 \mathrm{~g}$
\end{tabular}

Means for each attributes followed by the same letter are not significantly different at $5 \%$ level by Tukey.

Total Soluble Solids (TSS) - Total Soluble Solids of the juices indicate maturity of fruits used as reported by [42]. Total soluble solids of the treated samples were in the range of $42.83 \mathrm{mg} / \mathrm{L}-49.93 \mathrm{mg} / \mathrm{L}$ over 180 days storage period, while the control samples were between $15.62 \mathrm{mg} / \mathrm{L}-49.93 \mathrm{mg} / \mathrm{L}$ over the same period (Table 3). The stability of the total soluble solids of the juice indicates that the fruits were matured and could be responsible for good palatability and acceptability of the juice samples and could equally be attributed to the effects of the preservatives used. The slight decrease of TSS in the treated samples could be attributed to the effect of the preservative added, while larger decrease in the untreated samples might be due to the utilization of sugars by fermenting organisms leading to sugar degradation.

Total titratable acidity of the Samples was in the range of $0.14 \%-0.50 \%$ (Table 4 ) as malic acid present in the juice and was stable for over 14weeks of storage. The stability of the acidity indicates the concentration of organic acids mainly malic acid present in the juice to be stable. The decrease noticed in the titratable acidity might be due to the release of acids by decomposition, hydrolysis, oxidation or fermentation, which modifies the hydrogen ion concentration and consequently, food acidity. There were significant differences in the titratable acidity of the treated and untreated samples. There was increase in the titratable acidity of both the treated and untreated samples. The observed differences in the increase of the titratable acidity of both the treated and untreated samples 
could be attributed to the effect of the preservative used. Increase in titratable acidity of untreated samples compared to the treated ones showed that chemical degradation has been prevented in treated samples by the preservatives.

Table 3. Blends of Carrot, Oranges, Watermelon and Soymilk (mg/L Total Soluble Solids) Treatment with Aframomum danielli Powder (in grams)

\begin{tabular}{|c|c|c|c|c|c|c|c|}
\hline $\begin{array}{c}\text { Storage Time } \\
\text { (in weeks) }\end{array}$ & $3 g$ & $2.5 \mathrm{~g}$ & $2.0 \mathrm{~g}$ & $1.5 \mathrm{~g}$ & $1.0 \mathrm{~g}$ & $0.5 \mathrm{~g}$ & CTR \\
\hline 0 & 49.93a & 49.93a & 49.93a & 49.93a & 49.93a & 49.93a & $49.93 a$ \\
\hline 4 & 49.81a & $48.40 \mathrm{~b}$ & 48.39a & $49.92 \mathrm{a}$ & 48.61b & $46.43 b$ & $48.92 \mathrm{~b}$ \\
\hline 8 & 49.32a & 45.51c & $43.44 \mathrm{c}$ & 48.91b & 48.72b & $47.52 b$ & 49.63a \\
\hline 12 & $46.21 b$ & 43.74d & 35.09d & $45.53 c$ & $47.90 \mathrm{c}$ & $46.23 c$ & $29.72 c$ \\
\hline 16 & 44.81c & 39.82e & 29.19e & 42.69d & $47.86 \mathrm{c}$ & 43.53d & $18.31 d$ \\
\hline 20 & 43.21c & $34.96 f$ & 28.75e & $38.26 \mathrm{e}$ & $42.68 \mathrm{e}$ & $37.92 \mathrm{e}$ & $17.44 d$ \\
\hline 24 & 28.30d & $28.03 \mathrm{~g}$ & 27.93f & $28.62 f$ & 26.91e & $26.83 f$ & $15.62 \mathrm{e}$ \\
\hline$\%$ loss & 43.32 & 43.86 & 44.06 & 42.68 & 46.10 & 46.26 & 68.72 \\
\hline
\end{tabular}

Means for each attributes followed by the same letter are not significantly different at 5\% level by Tukey.

Table 4. Blends of Carrot, Oranges, Watermelon and Soymilk (\% TTA) Treatment with Aframomum danielli Powder (in grams)

\begin{tabular}{ccccccccc}
\hline $\begin{array}{c}\text { Storage Time } \\
\text { (in weeks) }\end{array}$ & $\mathbf{3 . 0 g}$ & $\mathbf{2 . 5 g}$ & $\mathbf{2 . 0 g}$ & $\mathbf{1 . 5 g}$ & $\mathbf{1 . 0 g}$ & $\mathbf{0 . 5 g}$ & $\mathbf{C T R}$ \\
\hline 0 & $0.14 \mathrm{f}$ & $0.08 \mathrm{e}$ & $0.14 \mathrm{f}$ & $0.08 \mathrm{e}$ & $0.12 \mathrm{~g}$ & 0.16 & $0.04 \mathrm{e}$ \\
4 & $0.21 \mathrm{e}$ & $0.12 \mathrm{~d}$ & $0.18 \mathrm{e}$ & $0.11 \mathrm{~d}$ & $0.14 \mathrm{~d}$ & $0.18 \mathrm{e}$ & $0.07 \mathrm{e}$ \\
8 & $0.28 \mathrm{~d}$ & $0.14 \mathrm{~d}$ & $0.20 \mathrm{e}$ & $0.16 \mathrm{c}$ & $0.19 \mathrm{e}$ & $0.23 \mathrm{~d}$ & $0.10 \mathrm{~d}$ \\
12 & $0.35 \mathrm{c}$ & $0.16 \mathrm{c}$ & $0.27 \mathrm{~d}$ & $0.21 \mathrm{~b}$ & $0.24 \mathrm{~d}$ & $0.27 \mathrm{c}$ & $0.15 \mathrm{c}$ \\
16 & $0.40 \mathrm{~b}$ & $0.18 \mathrm{c}$ & $0.38 \mathrm{c}$ & $0.24 \mathrm{~b}$ & $0.29 \mathrm{c}$ & $0.34 \mathrm{~b}$ & $0.18 \mathrm{c}$ \\
20 & $0.51 \mathrm{a}$ & $0.27 \mathrm{~b}$ & $0.47 \mathrm{~b}$ & $0.32 \mathrm{a}$ & $0.33 \mathrm{~b}$ & $0.36 \mathrm{~b}$ & $0.27 \mathrm{~b}$ \\
24 & $0.50 \mathrm{a}$ & $0.34 \mathrm{a}$ & $0.50 \mathrm{a}$ & $0.34 \mathrm{a}$ & $0.39 \mathrm{a}$ & $0.44 \mathrm{a}$ & $0.57 \mathrm{a}$ \\
\hline
\end{tabular}

Means for each attributes followed by the same letter are not significantly different at $5 \%$ level by Tukey.

Ascorbic acid is an index of nutrient quality of fruits and vegetable and much more sensitive to various modes of degradation in food processing and subsequent storage [32,37]. Ascorbic acid is also used as a standard for monitoring the quality of juices in storage. Vitamins $\mathrm{C}$ content of the juice was $0.64 \pm 0.0 \mathrm{mg} / \mathrm{ml}$ and was stable for over 12weeks before slight degradation started. Between 8\%-13\% degradation was observed in the treated samples over the storage period, while untreated sample had over 35\% degradation for the same period of storage (Table 5).

Table 5. Blends of Carrot, Oranges, Watermelon and Soymilk (Vit C in mg/ml) Treatment with Aframomum danielli Powder (in grams)

\begin{tabular}{|c|c|c|c|c|c|c|c|}
\hline $\begin{array}{l}\text { Storage Time } \\
\text { (in weeks) }\end{array}$ & $3 g$ & $2.5 \mathrm{~g}$ & $2.0 \mathrm{~g}$ & $1.5 \mathrm{~g}$ & $1.0 \mathrm{~g}$ & $0.5 \mathrm{~g}$ & CTR \\
\hline 0 & 0.64a & 0.64a & $0.64 a$ & $0.64 a$ & 0.64a & $0.64 a$ & $0.64 \mathrm{a}$ \\
\hline 4 & $0.61 \mathrm{a}$ & 0.63a & $0.63 a$ & $0.62 \mathrm{a}$ & $0.64 a$ & $0.64 a$ & $0.57 \mathrm{~b}$ \\
\hline 8 & $0.61 \mathrm{a}$ & $0.62 a$ & $0.61 \mathrm{a}$ & 0.63a & $0.63 a$ & $0.62 a$ & $0.51 \mathrm{c}$ \\
\hline 12 & 0.60a & $0.60 \mathrm{a}$ & $0.61 \mathrm{a}$ & $0.61 \mathrm{a}$ & $0.63 a$ & $0.60 \mathrm{c}$ & $0.44 d$ \\
\hline 16 & $0.57 \mathrm{~b}$ & $0.60 \mathrm{a}$ & $0.61 \mathrm{a}$ & $0.60 \mathrm{a}$ & $0.62 \mathrm{a}$ & $0.60 \mathrm{~b}$ & $0.44 d$ \\
\hline 20 & $0.57 b$ & $0.59 b$ & $0.60 \mathrm{a}$ & $0.59 b$ & $0.61 \mathrm{a}$ & $0.59 b$ & $0.41 \mathrm{~d}$ \\
\hline 24 & $0.56 \mathrm{~b}$ & $0.58 \mathrm{ba}$ & $0.59 b$ & $0.58 b$ & $0.59 b$ & $0.58 \mathrm{~b}$ & $0.40 \mathrm{e}$ \\
\hline$\%$ loss & 12.75 & 9.49 & 8.71 & 9.33 & 7.62 & 9.18 & 38.41 \\
\hline
\end{tabular}

Means for each attributes followed by the same letter are not significantly different at $5 \%$ level by Tukey.

Higher losses in the untreated samples are probably due to the absence of preservatives. The decrease observed could also be attributed to oxidation, which occurs in fruit juices during storage and is highly dependent on the presence of oxygen in the head space or dissolve in the juice [11]. Some other researchers have reported decrease of Vitamin C in stored juices. Concord grape juice preserved with potassium sorbate and stored in glass bottles at $37^{\circ} \mathrm{C}$ retained much of its ascorbic acid for five months [38] and orange juice packed in glass bottles was reported to maintain ascorbic acid concentration for 112 days at $22^{\circ} \mathrm{C}$ [4]. It was also reported by [11] that $25.65 \%$ decrease was observed for hot fill and $26.74 \%$ for aseptic method after 350days of storage. According to [23], orange juice should contain at least $25 \mathrm{mg}$ vitamin $\mathrm{C}$ per $100 \mathrm{ml}$ at the time of expiration, which is about $50 \%$ of initial amount. Ascorbic acid loss of between 8 and 13\% in the Aframomum danielli treated samples indicated that the preservative helped in preventing degradation and assist in the retention of over half of the ascorbic acid contained initially.

Total sugars (Table 6) were stable over the period of storage. Between 1\%-5\% of total sugars were lost in the treated samples after 24 weeks of storage, while untreated samples lost over $8 \%$ of its sugars over the same period. The loss recorded might be due to non-enzymatic 
browning reactions, either caramelization or maillard reactions occurring between amino acids or reducing sugars. Non enzymatic browning during processing or storage of juices may affect the flavour, colour, or other quality factors of the product. It is the most complex reaction in food chemistry due to the large number of food components able to participate in the reaction through different part ways giving rise to a complex mixture of products.

Table 6. Blends of Carrot, Oranges, Watermelon and Soymilk (\% Sugar) Treatment with Aframomum danielli Powder (in grams)

\begin{tabular}{|c|c|c|c|c|c|c|c|}
\hline $\begin{array}{c}\text { Storage Time } \\
\text { (in weeks) }\end{array}$ & $3 g$ & $2.5 \mathrm{~g}$ & $2.0 \mathrm{~g}$ & $1.5 \mathrm{~g}$ & $1.0 \mathrm{~g}$ & $0.5 \mathrm{~g}$ & CTR \\
\hline 0 & 19.61a & 19.61a & 19.61a & 19.61a & 19.61a & 19.61a & $19.61 \mathrm{a}$ \\
\hline 4 & $19.51 b$ & 19.60a & $19.52 b$ & 19.50b & $19.50 \mathrm{~b}$ & $19.42 \mathrm{c}$ & $18.82 b$ \\
\hline 8 & 19.30c & $19.49 b$ & $19.45 \mathrm{c}$ & $19.46 \mathrm{bc}$ & $19.53 b$ & 19.52b & $18.43 d$ \\
\hline 12 & 19.23d & $19.50 \mathrm{~b}$ & 19.41d & $19.48 b c$ & $19.54 b$ & $19.50 \mathrm{~b}$ & $18.54 \mathrm{c}$ \\
\hline 16 & $19.20 d$ & 19.31c & $18.88 \mathrm{c}$ & 19.39c & $19.21 \mathrm{c}$ & $19.40 \mathrm{c}$ & $18.27 \mathrm{c}$ \\
\hline 20 & 19.09de & 19.20d & $18.72 \mathrm{f}$ & $19.28 d$ & 19.03d & $19.38 \mathrm{~cd}$ & $18.12 \mathrm{f}$ \\
\hline 24 & $18.99 \mathrm{e}$ & $19.14 \mathrm{e}$ & $18.53 g$ & $19.25 d$ & 18.93e & 19.21d & $17.90 \mathrm{~g}$ \\
\hline$\%$ loss & 3.16 & 2.40 & 5.51 & 1.84 & 3.47 & 2.04 & 8.72 \\
\hline
\end{tabular}

Means for each attributes followed by the same letter are not significantly different at $5 \%$ level by Tukey.

\section{Conclusion}

The results of the experiment confirmed that Aframomum danielli powder is a good natural additive for the preservation of the physico-chemical properties of soymilk-based juice. It effectively retained the nutritional qualities of the juice, as attested to by the stability of total soluble solids, vitamin $\mathrm{C}$ and total sugar contents of the juice. Sensory attributes of the juice was accepted. The local spice, Aframomum danielli, utilized in the research work is cheap, available and has no recorded side effect. The use of Aframomum danielli powder in the preservation of juice products and other food should be encouraged.

\section{References}

[1] Adefegha SA and Oboh G (2011a). Enhancement of Total phenolics and Antioxidant Properties of Some Tropical Green Leafy Vegetables by Steam Cooking. J. Food Process. Preserv. 35(5): 615-622.

[2] Adegoke OA, Makinde O, Falade KO, Uzo - Peters PI (2003). Extraction and Characterization of Antioxidants from Aframomum melegueta and Xylopia Aethiopica_Eur. Food Res. Technol 216: 526-528.

[3] Allende A. Tomas-Barberan FA, Gil MI (2006). Minimal Processing for Healthy Traditional Foods. Trends in Food Science and Technology. 17:513-519.

[4] Ayhan Z, Yeom H, Zhang Q and Min DB (2001). Flavour, colour and vitamin $C$ retention of pulsed electric field processed orange juice in different packaging materials. Journal of Agriculture and Food Chemistry 49: 669-74.

[5] Azoubel PM, El-Aouar EA, Tonon RV, Kurozawa LE, Antonio GC, Murr FEX, Park KJ (2009). Effect of Osmotic Dehydration on the Drying Kinetics and Quality of Cashew Apple. Int. J. Food Sci. Tech. 44:980-986.

[6] Bhagwat AA (2006). Microbiological Safety of Fresh-cut Produce: Where are we now? In: Matthew KR, eds. Microbiology of Fresh Produce. Washington, DC: ASM Press: 121-165.

[7] Butz P, Needs EC, Baron A, Bayer O, Geisel B, Gupta B, Oltersdorf U, Tauscher B (2003). Consumers' attitude to high pressure food processing. Food, Agriculture and Environment, 1, pp.30-34.

[8] Calisir S, Haciseferogullari H, Ozcan M, Arslan D (2005). Some Nutritional and Technological Properties of Wild Plum (Prunus spp.) fruits in Turkey, J. Food Eng. 66:233-237.

[9] Campos DCP, Santos AS, Wolkoff DB, Matta VM, Cabral LMC, Couri S. (2002). Cashew Apple Juice Stabilization by Microfiltration. Desalination. 148: 61-65.
[10] Corbo MR. Bevilacqua A, Campaniello D, D’Amato D. Speranza B, Sinigaglia M (2009). Prolonging Microbial Shelf Life of Foods through the Use of Natural Compounds and Non-thermal Approaches-a review. International Journal of Food Science and Technology. 44: 223-241.

[11] Costa MCO, Maia GA, Figueiredo RW, Souza Filho MM, Brasil IM (2003). Storage Stability of Cashew Apple Juice Preserved by Hot Fill and Aseptic Processes. Cienc Tecnol. Aliment. Campinas. 23 (Supl): 106-109.

[12] Deliza R, Rosenthal A, Abadio FBD, Silva CHO, Castillo C (2005). Application of high pressure technology in the fruit juice processing: benefits perceived by consumers. Journal of Food Engineering, 67, pp. 241-246.

[13] Dhuique-Mayer C, Caris-Veyrat C, Ollitrault P, Curk F, Amiot MJ (2005). Varietal and interspecific influence on micronutrient contents in citrus from the Mediterranean area. Journal of Agriculture and Food chemistry. 53, 2140-2145.

[14] Diaz-Mula HM, Javier Zapata P, Guillen F, Castillo S, MartinezRomero D, Valero D, Serrano M (2008). Changes in Physicochemical and Nutritive Parameters and Bioactive Compounds during Development and on-tree Ripening of Eight Plum Cultivars: A Comparative Study. J. Sci. Food Agric. 88(14):2499-2507.

[15] Diplock AT (1994). Antioxidants and diseases prevention. Molecular Aspects of Medicine. 15, 293-376.

[16] Ertekin C, Gozlekci S, Kabas O, Sonmez S, Akinci I (2006). Some Physical, Pomological and Nutritional Properties of Two Plum (Prunus domestica L.) cultivars. J. Food Eng. 75(4):508-514.

[17] Fasoyiro SB, Adegoke GO, Obatolu VA, Ashaye O, Aroyeun SO (2001a). The antioxidant property of Aframomum danielli in oils. J. Food Technol. Africa 6: 135-137.

[18] Garcia-Closas R, Gonzales C, Aguda A, Riboli E (1999). Intake of specific carotenoids and flavonoids and the risk of gastric cancer in Spain. Cancer Causes Control. 10, 71-75.

[19] Gorinstein S, Martin-Belloso O, Park YS, Haruenkit R, Lojek A, $\mathrm{Ciz}$ M (2001). Comparison of some biochemical characteristics of different citrus fruit. Food Chemistry, 74, 309-315.

[20] Hertog GL, Hollman PCH, Van de Putte B (1993). Content of potentially anticarcinogenic flavonoids of tea infusion, wine, and fruit juices. Journal of Agriculture and Food Chemistry, 74, 19371941.

[21] Jatto WO and Adegoke GO (2010). Storage Studies on cashew Juice preserved with water extracted Aframomum danielli. Elect. J. Env. Agric. Food Chem. 9: 1351-1359.

[22] Khazaei J, Mann DD (2004). Effects of temperature and loading characteristics on mechanical and stress-relaxation properties of sea buckthorn berries, Part 1, Compression tests. Agricultural Engineering International: The CIGR J. Scientific Res. Development, Manuscript FP 03011.

[23] Kimball D (1991). Citrus Processing: Quality control and Technology. Van Nostrand Reinhold: New York.

[24] Knekt P, Jarvinen R, Seppanen R, Heliovaara M, Teppo L, Pukkala E (1997). Dietary flavonoids and the risk of lung cancer and other malignant neoplasms. American Journal of Epidemiology. 146, 223-230. 
[25] Lock JM (1985). Zingiberaceae. In Balkema, A. A. Flora of Tropical East Africa Polhill (ed.) Rotterdam pp. 1-2.

[26] Lu M, Yuan B, Zeng M, Chen J (2011). Antioxidant capacity and major phenolic compounds of spices commonly consumed in China. Food Res. Int. 44:530-536.

[27] Molina JM, Calvo D, Medina JJ, Barrau C, Romero F. (2008). Fruit Quality Parameters of Some Southern Highbush Blueberries (Vaccinium Xcorymbosum L.) grown in Andalusia (Spain). Spanish J. Agric. Res. 6(4):671-676.

[28] Naderiboldaji M, Khadivi Khub A, Tabatabaeefar A, Ghasemi Varnamkhasti M, Zamani Z (2008). Some Physical Properties of Sweet Cherry (Prunus avium L.) Fruit, American-Eurasian J. Agria Environ. Sci. 3(4):513-520.

[29] Oboh G and Rocha JBT (2007). Antioxidants in Foods: A New Challenge for Food processors. Leading Edge Antioxidants Research, Nova Science Publishers Inc. New York US, 35-64.

[30] Odukoya AO, Ilori OO, Sofidiya MO, Aniunoh OA, Lawal BM, Tade IO (2005). Antioxidant activity of Nigerian dietary spices. Electr. J. Environ. Agric. Food Chem. 4(6): 1086-1093.

[31] Olivas GI, Barbosa-Canovas GV (2005). Edible Coatings for Fresh-cut Fruits. Critical Reviews in Food Science and Nutrition. ; 45: 657-663.

[32] Ozkan M, Kirca A and Cameroglu B (2004). Effect of hydrogen peroxide on the stability of ascorbic acid during storagein various fruit juices. Food Chemistry, 88:591-597.

[33] Polat AA, Durgac C, Kamiloglu, O (2008). Determination of Fruit Quality Parameters of Sweet Cherries Grown in High Elevation Regions in Hatay, Turkey. Acta Hortic. 795(2): 873-876.

[34] Radicevic S, Cerovic R, Mitrovic O, Glisic I (2008). Pomological Characteristic and Biochemical Fruit Composition of Some Canadian Sweet Cherry Cultivars. Acta Hortic. 795(1): 283-286.

[35] Ragaert P, Verbeke W, Devlieghere F, Debevere J (2004). Consumer Perception and Choice of Minimally Processed Vegetables and Packaged Fruits. Food Quality and Preference. 15: 259-270.
[36] Rapisarda P, Tomaino A, Lo Cascio R, Bonina F, De Pasquale A, Saija A (1999). Antioxidant effectiveness as influenced by phenolic content of fresh orange juices. Journal of Agriculture and Food Chemistry, 47, 4718-4723.

[37] Shaw PE (1992). Shelf life and aging of citrus juices, drinks and related soft drinks. In: Quality control manual for citrus processing plants. Redd JB, Shaw PE and Hendrix DL (Eds.) Aubandale, Agricscience. Florida: 173-179.

[38] Siler A and Morris JR (1993). Quality effects of carbonation and ethyl maltol on Venus and Concord Juices and their Grape- Apple blends. American Journal of Enology and Viticulture. 44: 320-326.

[39] Stone $H$ and Sidel JL (1992). Sensory evaluation practices. $2^{\text {nd }}$ ed. San Diego: Elsevier, pp. 336.

[40] Topuz A, Topakci M, Canakci M, Akinci I, Ozdemir F (2004). Physical and Nutritional Properties of Four Orange Varieties, J. Food Eng. 66:519-523.

[41] Torres JA and Velazquez G (2005). Commercial opportunities and research challenges in the high pressure processing of foods. Journal of Food Engineering, 67, pp. 95-112.

[42] Uma Talasila, Rama Rao Vechalapu and Khasim Beebi Shaik (2011). Preservation and Shelf life Extension of Cashew Apple Juice. Internet Journal of Food Safety, Vol. 13, p275-280.

[43] Van den Heuvel T, Trijp H, van Woerkum C, Renes RJ, Gremmen B (2007). Linking product offering to consumer needs: inclusion of credence attributes and the influences of product features. Food Quality and Preference, 18, pp. 296-304.

[44] Vursavus K, Kelebek H, Selli S (2006). A Study on Some Chemical and Physico-Mechanism Properties of Three Sweet Cherry Varieties (Prunus avium L) in Turkey. J. Food Eng. 74(4): 568-575.

[45] Wong P, Yusof S, Ghazali HM and Cheman YB (2003). Optimization of hot water extraction of roselle juice using response surface methodology: a comparative study with other extraction methods. Journal of Science of Food and Agriculture 83: 1273-1278. 